\title{
Comedy, Satire, Paradox, and the Plurality of Discourses in Cinquecento Italy: Introduction
}

STEFANO JOSSA AND AMBRA MORONCINI

Royal Holloway University of London and University of Sussex

$\mathrm{I}^{\mathrm{n}}$ n early modern Italy, specifically in the sixteenth century, comedies, satirical works, and paradoxical verse and prose contributed to the rich and varied facets of Renaissance culture to such an extent that critical perspectives on the heterogeneous production of these most dissimulating of genres might result in broader interpretations than scholarship has so far acknowledged, not least because "popular theatre, particularly in rural areas, was resistant but undocumented." ${ }^{2}$ The commedia erudita-the Italian vernacular comedy of the sixteenth century written in emulation and imitation of the two ancient Roman playwrights Plautus and Terence-was a genre in which Ariosto and Machiavelli excelled, but which never reached the same high status as the more classical genres of epic poetry and tragedy. The alleged "desolante uniformità del teatro comico del Cinquecento" ("dismaying uniformity of Cinquecento theatre") and "the heavy hand of the Roman playwrights and theorists" were considered to have inhibited the natural comic spirit of the Italians, "leaving the best fruits of the comic tradition to be plucked by the more independent dramatists of Spain and England." ${ }^{2}$ Satire, on the other hand, despite being a

1. Richard Andrews, "Theatre," in The Cambridge History of Italian Literature, ed. Peter Brand and Lino Pertile (Cambridge and New York: Cambridge University Press, 1999), 277-98, 277.

2. Ireneo Sanesi, Storia dei generi letterari italiani. La Commedia, 2 vols. (Milan: Vallardi, 1911), 1:223-377, 230, and Charles P. Brand, "The Renaissance of Comedy: The Achievement of Italian Commedia Erudita," The Modern Language Review 90.4 (1995): xxix-xlii, xxix. See also Donald Beecher, "Introduction: 'Erudite' Comedy in Renaissance Italy," in Renaissance Comedy: the Italian Masters, ed. Donald Beecher. 2 vols. (Toronto and London: University of Toronto Press, 2008), 1:3-35; Jackson I. Cope, "Plautus, New Comedy, and the Anti-Plautine," in Secret Sharers in Italian Comedy: From Machiavelli to Goldoni (Durham and London: Duke University Press, 1996), 1-13; Douglas RadcliffUmstead, The Birth of Modern Comedy in Renaissance Italy (Chicago and London: University of Chicago Press, 1969), especially 1-22; Nino Borsellino, "Introduzione," in Commedie del Cinquecento, 2 vols. (Turin: Feltrinelli, 1962), 1:ix-xxxix. For Ariosto's comic theatre, see Ludovico Ariosto, Tutte le commedie, 3 vols., ed. Luigina Stefani (Perugia: Morlacchi, 2013), especially the excellent "Introduction" 
classical genre (Roman satura), has been recognized since at least the late 1400s as above all "an attitude, a technique, and an ethical and moral code," though it is precisely its development that enables us to get an enhanced understanding of the Italian comic tradition. ${ }^{3}$ Additionally, scant critical attention has been paid to Renaissance paradoxical texts: a genre perceived as "an apparently perverse literary form," even though it rivalled the epigram and even the sonnet in popularity. ${ }^{4}$ Hence, if one considers the strength and diversity of the many Renaissance discourses of serio ludere (i.e., the humorous literature concealing serious meaning), as well as issues concerning the nature of audiences and the occasions that might have prompted the composition of the commedia erudita, ${ }^{5}$ then a reappraisal of the Italian comic genres of the Cinquecento may be inevitable so as to reassess the critical discourse on major and minor

(1:1-90). For Machiavelli's comedies, see The Comedies of Machiavelli, ed. and trans. David Sices and James B. Atkinson (Hanover: University Press of New England, 1985), as well as Roberto Ridolfi, Studi sulle commedie del Machiavelli (Pisa: Nistri-Lischi, 1968).

3. Bernd Renner, "From Satura to Satyre: François Rabelais and the Renaissance Appropriation of a Genre," Renaissance Quarterly 67.2 (2014): 377-424, 377. See also Anne Lake Prescott, "Humour and Satire in the Renaissance," in The Cambridge History of Literary Criticism, 9 vols. (Cambridge: Cambridge University Press, 1999), 3:284-82, and Vittorio Cian, Storia dei generi letterari italiani. La Satira, 2 vols. (Milan: Vallardi, 1924-39).

4. A. E. Malloch, "The Techniques and Function of the Renaissance Paradox," Studies in Philology 53:2 (1956): 191-203, 191. See also Maria Cristina Figorilli, Meglio ignorante che dotto. L'elogio paradossale nel Cinquecento (Naples: Liguori, 2008); Antonio Corsaro's introduction to Ortensio Lando, Paradossi, cioè sentenze fuori del comun parere, ed. Antonio Corsaro (Rome: Edizioni di Storia e Letteratura, 2000), 1-25; Adrienne Laskier Martín, "Francesco Berni and the Burlesque Sonnet in the Sixteenth Century," in Cervantes and the Burlesque Sonnet (Los Angeles: University of California Press, 1991), 30-40; Silvia Longhi, Lusus: Il capitolo burlesco del Cinquecento (Padova: Antenore, 1983).

5. See Richard Andrews, Scripts and Scenarios: The Performance of Comedy in Renaissance Italy (Cambridge: Cambridge University Press, 1993), and Giorgio Padoan, L'avventura della commedia rinascimentale (Padua: Piccin Nuova Libraria, 1996). For the interchange between dramatic production and a fervid oral tradition, as well as for a dynamic circuit of representational practices and ceremonies, see also Interactions between Orality and Writing in Early Modern Italian Culture, ed. Luca Degl'Innocenti, Brian Richardson, and Chiara Sbordoni (New York: Routledge, 2016); Peter Burke, "Performing History: The Importance of Occasions," Rethinking History 9.1 (2005): 35-52; Peter Burke, The Historical Anthropology of Early Modern Italy (Cambridge: Cambridge University Press, 1987), 79-94. 
literary productions of the Italian Renaissance, in addition to the transgressive overtones of official comic fiction. ${ }^{6}$

In 1969, Paul F. Grendler's book Critics of the Italian World paved the way in the English-speaking world for the re-evaluation of the "other side" of Italian Renaissance culture; however ideological, his book offered a rare opportunity for further investigation, which has borne only limited fruit so far. Much work has been carried out in Italy, France, and the Netherlands in recent years on the unorthodox culture of Renaissance Italy by Cinquecento Plurale, an international network of scholars dedicated to research on heterodox aspects of the Italian Renaissance that criticism has traditionally neglected. Their ongoing work on religious, political, artistic, and literary sixteenth-century heterodoxy highlights the width and variety of counter-discourses in Renaissance Italy, to the extent that Renaissance personalities and works that had been previously marginalized have now achieved prominent status in scholarly research. ${ }^{8}$ Not less significant to a more plural notion of early modern Italian theatre have been works conducted in the English-speaking world on female comic writers, as well as on issues relating to gender roles in the Italian stage, "feminine fatherhood," patriarch masculinities, and family dramas of the urban middle class. $^{9}$ The broader web of relations that anti-conformist Renaissance writers

6. For an overview on "Classicism" and on "the anti-classicist tradition: parody, satire, burlesque" in sixteenth-century Italian literature, see the section on "Lyric Poetry" by Anthony Oldcorn in The Cambridge History of Italian Literature, ed. Brand and Pertile, 251-76. For theatre and drama studies indicating the extent to which in early modern Italy the framework of theatrical experience overcame traditional distinctions between high and low culture, see Siro Ferrone, La commedia dellarte. Attrici e attori italiani in Europa (XVI-XVIII sec.) (Milan: Mondadori, 2014); Siro Ferrone, Attori mercanti corsari (Turin: Einaudi, 1993); Luciano Zorzi, Il teatro e la città. Saggi sulla scena italiana (Turin: Einaudi, 1977).

7. Paul F. Grendler, Critics of the Italian World, 1530-1560: Anton Francesco Doni, Nicolò Franco and Ortensio Lando (Madison, Milwaukee, and London: University of Wisconsin Press, 1969).

8. Cinquecento plural website: http://www.nuovorinascimento.org/cinquecento/. See also Gli 'irregolari' nella letteratura. Eterodossi, parodisti, funambolisti della parola (Atti del Convegno. Catania 31 ottobre - 2 novembre 2005) (Rome: Salerno Editrice, 2007).

9. See, for instance, Yael Manes, Motherhood and Patriarchal Masculinities in Sixteenth-Century Italian Comedy (Burlington, VT and Farnham, UK: Ashgate, 2011); Laura Giannetti, "Ma che potrà succedermi se io donna amo una Donna; Female-Female Desire in Italian Renaissance Comedy," in Italy in the Drama of Europe, ed. Albert Russell Ascoli and William West, special double issue of Renaissance Drama 36/37 (Evanston: Northwestern University Press, 2010): 99-126; Andrew Richard, "Isabella Andreini and Others: Women on Stage in the Late Cinquecento," in Women in Italian Renaissance Culture and 
put in place through the interaction between "low" and "high" culture, and between true and false transgression, does however encourage further research, so as to get a more in-depth understanding of the complexity of discourses of what Giancarlo Mazzacurati provocatively called the various Renaissances of sixteenth-century culture in Italy and Europe. ${ }^{10}$

In 1991, in a memorial lecture to celebrate the work of the Italian art historian Eugenio Battisti, the scholar who in 1962 first coined the notion of antirinascimento (i.e., the counter-culture of Italian Renaissance), Umberto Eco famously claimed that Battisti's notion of antirinascimento had become our reading of the Renaissance. ${ }^{11}$ We object to branding the complexity of Renaissance culture with such labels as antirinascimento, and have been keen to promote a wider and more nuanced sixteenth-century Italian culture. To this end, the nine essays presented in this volume look at selected comic and satirical texts in sixteenth-century Italy with the aim of investigating the plurality of discourses (aesthetic, linguistic, political, religious, sexual, and scientific) adopted by some of the most influential Italian Renaissance writersspecifically Machiavelli, Ariosto, and Aretino-and lesser-known yet equally thought-provoking authors: Niccolò Franco, Annibal Caro, Giovan Battista Della Porta, and the painter Agnolo Bronzino. Our nine essays will represent individual case studies that by no means are intended to characterize the whole of Renaissance comic discourses, as more consideration to women writers in the light of the plurality of discourses suggested here will certainly be needed

Society, ed. Letizia Panizza (Oxford: Legenda, 2000), 316-33; Andrew Richard, "Anti-Feminism in commedia erudite," in Contexts of Renaissance Comedy, ed. Janet Clare and Roy Eriksen (Oslo: Novus Forlag, 1997), 11-31; Maggie Günsberg, "Gender Deceptions: Cross Dressing in Italian Renaissance Comedy," in Panizza, ed., 334-49; Maggie Günsberg, Gender and the Italian Stage: From the Renaissance to the Present Day (Cambridge and New York: Cambridge University Press, 1997).

10. Giancarlo Mazzacurati, 'La disseminazione dei 'rinascimenti', in Rinascimenti in transito (Rome: Bulzoni, 1996), 189-204. See also Alison Brown, "Rethinking the Renaissance in the Aftermath of the Italy's Crisis," in Italy in the Age of the Renaissance 1300-1550, ed. John N. Najemy (Oxford: Oxford University Press, 2004), 254-59, and Rewriting the Renaissance: The Discourses of Sexual Differences in Early Modern Europe, ed. Margaret W. Ferguson et al. (Chicago: University of Chicago Press, 1986).

11. Umberto Eco, "Battisti e l'antirinascimento," in Eugenio Battisti. Storia, critica, progetto nella continuità della ricerca (Convegno Internazionale, Milano 4 maggio, 2009), ed. Antonio Piva and Pierfranco Galliani (Rome: Gangemi Editore, 2011), 119-27; Umberto Eco, "Un ricordo di Eugenio Battisti," Arte lombarda 105-07 (1993): 167-69. See also Eugenio Battisti, Lantirinascimento (Milan: Feltrinelli, 1962). 
in the near future. Nevertheless, independently of gender issues, we hope to demonstrate that in the Cinquecento, Italian comedies, satirical works, and paradoxical verse and prose developed discourses other than those of official courtesan literature.

In organizing the essays of our collection, we have followed a thematic approach, rather than a chronological one, acknowledging two broad areas in the interaction between comedic and comic discourse, on the one hand, and issues of self-fashioning and anti-Petrarchism, on the other. The diverse theatrical discourses in force in sixteenth-century Italy will start our volume with essays by Konrad Eisenbichler ("Sex and Marriage in Machiavelli's Mandragola: A Close(t) Reading"), Daragh O'Connell ("Ariosto's Astute Arrogance: The Construction of the Comic City in La Lena"), Ambra Moroncini ("Érasme, l'Arétin et Boccace dans l'invention du discours comique-burlesque d'Annibal Caro"), Enrica Maria Ferrara ("The Reception of Fernando de Roja’s Celestina in Italy: A Polyphonic Discourse"), and Eugenio Refini ("Bodily Passions: Physiognomy and Drama in Giovan Battista Della Porta").

In our first essay, Eisenbichler considers the conquestio uxoris in order to outline a new critical reading of Machiavelli's play from the perspective of sex and gender studies. His examination reveals that, under the cover of entertainment and humour, Machiavelli was raising important questions about contemporary marriage patterns and sexual practices that ranged from the matter of a man's "honour" to the topic of a woman's "worth," as well as from the difference in age between the spouses to the difference in their sexual interests.

Giovan Battista Giraldi Cinzio, a fellow-citizen and partisan of Ariosto, claimed that "laudable comedies are only those that imitate Ariosto's ones." ${ }^{2}$ The next article, by O'Connell, looks at La Lena to present new lines of investigation into one of the most accomplished examples of commedia erudita. Constituting both a textual and scenic overhauling of Plautine theatrical models, La Lena is an ideal text to explore both the interplay between tradition and innovation, and the stage and its audience. This essay brings to light Ariosto's complex interplay of theatrical aspects with social satire and humanist, political, and ethical concerns.

12. "le (commedie) lodevoli sono di una sola maniera, et sono quelle che imitano quelle di Ariosto." Giovan Battista Giraldi Cinzio, Discorsi intorno al comporre rivisti dall'autore nell'esemplare ferrarese $\mathrm{Cl}$. I. 90., ed. Susanna Villari (Messina: Centro interdipartimentale di studi umanistici, 2002), 234. 
The following essay, by Moroncini, considers Annibal Caro's burlesque prose, as well his only comedy Gli Straccioni (The ragged brothers), in the climate of tense expectation in Rome for significant Church reform. The author argues that because of his courtly profession, not least his privileged position at the service of the Farnese family, Caro's religious beliefs never raised suspicion-even though, as her study will show, in the late 1530s Caro was actively involved in Rome in a sodalitas with strong connections to heterodox figures. At the request of these sodales he wrote paradoxical and enigmatic texts in which a Carnival context was used to conceal polemical comments against the corruption of the Roman Church. A not dissimilar discourse, Moroncini maintains, is pursued by Caro in the only comedy he wrote but never published and never allowed to be staged. Her essay explores likely conduits for Caro's discourse of serio ludere by examining some parallels with the literary and religious discourses adopted by Erasmus, Aretino, and Boccaccio.

In our fourth essay, Ferrara considers the impact and reception in early modern Italy of Fernando de Roja's Celestina. By focusing on the hybrid genre of the play, which can be placed at the crossroads of comic and tragic genres, but also on the boundaries between narrative and theatrical modes of expression, Ferrara demonstrates that the successful reception of this text in sixteenthcentury Italy and beyond is to be attributed to its attack on the hypocrisy of humanism and the pointlessness of Petrarchism.

Switching to a more scientific cultural perspective, our fifth essay, by Refini, explores the ways in which Della Porta's comic theatre interacts with the author's expertise in the field of physiognomy. By focusing on the rhetorical discussion of human passions, as well as on their theatrical representation, Refini shows how Della Porta challenges and reshapes the main assumptions relevant to physiognomy in order to make them fit with the comic mode.

Our second area of investigation is devoted to self-fashioning, antiPetrarchism, and Pasquinesque camouflage, with essays by Paola Ugolini ("SelfPortraits of a Truthful Liar: Satire, Truth-Telling, and Courtliness in Ludovico Ariosto's Satire and Orlando Furioso"), Marco Faini ("E poi in Roma ognuno è Aretino: Pasquino, Aretino and the Concealed Self"), Roland Béhar ("Il ridervi de la goffezza del dire: Niccolò Franco et la satire napolitaine du pétrarquisme"), and Carla Chiummo ("Burlesque Connotations in the Pictorial Language in Bronzino's Poetry"). 
Ugolini proposes a close reading of Ariosto's self-fashioning in both his Satire and Orlando Furioso, with the aim of overcoming the traditional opposition between satire as the mode for honest speech and epic as the mode for courtly flattering. Composed during the most difficult years of Ludovico Ariosto's relationship with the Este court, the satires are known for presenting a picture of their author as a simple, quiet-loving man ("Ludovico della tranquillità," in Antonio Baldini's definition), ${ }^{13}$ and also as a man who can speak only the truth ("esser non so se non verace," according to Ariosto's own statement in Satira III). However-as Ugolini points out-the self-portrait of the author as a man incapable of lying offered by the Satire stands in direct contrast to the depiction of all writers (and thus, implicitly, of the author as well) as liars, as presented by St. John in canto 35 of Orlando Furioso.

Ariosto's elusive self-fashioning may be not too different from Aretino's, as Marco Faini argues in his essay on Aretino's pasquinesque mask, hence bridging the gap between two authors who have usually been read as opposites to each other. Here we learn that while Aretino has long been identified with Pasquino, and his pasquinesque poetry has been considered his distinctive feature, only a rather small number of pasquinades can be attributed to the "scourge of princes." Nonetheless, Aretino let his name be associated with a number of pasquinades he had never written because he was attracted to Pasquino's lack of identity. Aretino's use of the genre of the pasquinate-Faini maintains - allowed him to shape his own identity without being trapped in the dominant dichotomies of his time, i.e., between courtliness and anti-courtliness or Petrarchism and anti-Petrarchism.

In line with the anti-Petrarchism vein in Renaissance comic discourses, Béhar's essay focuses on the satirical work of one of the most ferocious "critics of the Italian world," Niccolò Franco. Béhar argues that, although the extent to which Franco was indebted to Erasmus and Aretino is well known, more attention should be given to the Neapolitan background of Franco's education (until 1536), which is essential to the understanding of his key text Il Petrarchista. Recalling some passages of Fabrizio Luna's Vocabulario (1536) and especially of Benedetto Di Falco's Rimario (1535), this essay demonstrates that Franco's positions are rooted in satirical modes that were already in place in the Neapolitan tradition. 
Finally, Chiummo's essay deals with the burlesque connotations of the pictorial language in Agnolo Bronzino's poetry. Through a critical analysis of Bronzino's paradoxical capitoli and satirical sonnets, Chiummo sheds light on Bronzino's use of well-known burlesque symbols and metaphors adopted by the painter-poet for a more serious and complex discourse on aesthetic issues.

The nine essays collected in this volume address issues of sexuality, readership, authorship, identity, and religious and political dissent, and highlight the interactions between various genres, styles, and fields, thereby demonstrating the extent to which a plurality of discourses was inherent to what we call "Renaissance culture." Far from believing that we have assembled a complete picture of the plurality of comic and satirical discourses adopted in sixteenth-century Italy, we hope nonetheless to have brought to light significant research perspectives for further studies. We should like to warmly thank our contributors for their incredible enthusiasm in joining our project and bestow special thanks to Konrad Eisenbichler for the invaluable and generous attention he has given to our venture. 